\title{
Overview of Continental Shelf Elasmobranch Fisheries in the Cantabrian Sea
}

\author{
C. Rodríguez-Cabello, A. Fernández, I. Olaso, F. Sánchez, R. Gancedo, A. Punzón and O. Cendrero \\ Instituto Español de Oceanografía, Laboratorio Oceanográfico de Santander \\ Apdo. 240, 39080 Santander, Spain
}

Rodríguez-Cabello, C., A. Fernández, I. Olaso, F. Sánchez, R. Gancedo, A. Punzón, and O. Cendrero. 2005. Overview of Continental Shelf Elasmobranch Fisheries in the Cantabrian Sea. J. Northw. Atl. Fish. Sci., 35: 375-385. doi:10.2960/J.v35.m490

\begin{abstract}
Fisheries for the most common elasmobranch species landed in the Cantabrian Sea (ICES Division VIIIc) are reviewed. Special attention is given to small-spotted catshark (Scyliorhinus canicula) and the following Rajidae thornback ray (Raja clavata), spotted ray, (R. montagui) and cuckoo ray (Leucoraja naevus), representing more than the $90 \%$ of ray landings. A market sampling program was carried out in 2001 to improve the knowledge of species that are frequently landed as a mixed species assemblage, occasionally gutted, or in the case of rays, "wings" (pectoral fins retained). Commercial length distributions by gear, area and quarter are presented as well. Thirty-five percent of the catches in the trawl fishery are discarded. The estimated annual average of dogfish catch is about 1500 tons, $80 \%$ of which is discarded. In the case of ray species, the estimated annual catch is 600 tons, $\sim 30 \%$ being discarded.
\end{abstract}

Key words: by-catch, Cantabrian Sea, dogfish, fisheries, gear, length, rays, sharks

\section{Introduction}

The Cantabrian Sea is located in the southern part of the Bay of Biscay (ICES Division VIIIc, Fig. 1 and 2). Its continental shelf is narrow compared to adjacent areas such the French shelf. It is also characterized by canyons, and marginal shelves. The existence of slope currents and enriching upwellings together with the high diversity of bottom life contributes to the existence of a complex ecosystem. These factors together with the presence of many seasonally migratory species contribute greatly to the productive fisheries in this area (Sánchez et al., 1995; Sánchez and Olaso, 1999).

The spatial distribution, demographic composition and abundance indices of some of these species, based on bottom trawl surveys carried out by the Instituto Español de Oceanografía, is well documented (Sánchez, 1993; Sánchez et al., 2002). However, many of the elasmobranch species caught by the Spanish fleet are taken as by-catch in directed fisheries for other commercial species or in multi-species fisheries. As a consequence, fishery statistics are often available for mixed species groups, and seldom for single species. Advice for elasmobranch species or fisheries should be based on the best available data, both biological and, fishery and survey data. A first step towards stock assessment should be a review of national landings with respect to species composition and estimated quantity (Heessen, 2003).

To date, no baseline fisheries studies have been carried out on the elasmobranch species in this geographical area. Recently there has been a global increase in interest in elasmobranchs, particularly in the need for management advice (IMM, 1997; ICES, MS 1997). The main problem is a basic lack of biological information and appropriate fisheries data to be used in assessments. The EU-funded study DELASS (Development of Elasmobranch Assessments) was specifically intended to stimulate the development of methods to asses the status of elasmobranch stocks to improve the scientific basis for the management of fisheries taking these species. This study was developed within this framework: to increase our knowledge of elasmobranch fisheries in this area.

Spanish landings of elasmobranch species by fishing gear in the Cantabrian Sea have been compiled from 1996 to 2001. Special attention has been paid to rays and dogfish species and length composition by gear.

\section{Methods}

Landings have been collected on a monthly basis from most of the fishing ports along the north coast of Spain during 1996 to 2001 (Fig. 1). A total of 45 fishing ports were regularly monitored; information on landings (kg), type of gear and fishing areas was obtained for each month from official statistics provided by various fisheries associations. For pelagic sharks, only landings from ICES Division VIIIc, including data from the fishery in the Basque Country were considered in this paper. Data on the by-catch of the Spanish longline fishery targeting swordfish in North Atlantic waters and Mediterranean Sea have not been included because they are from outside 
the area studied. Statistics for pelagic sharks are found in ICCAT (Kebe et al., 2002). Estimates of the by-catch for associated fisheries are available for 1997, 1998 and 1999 respectively (Buencuerpo, et al., 1998; Castro et al., 2000; Mejuto et al., 2002).

A market sampling program has been carried out under the DELASS project during 2000-01; to obtain the length compositions of several elasmobranch species by gear, to identify the species of rays landed (from mixed round or wings landings) and to obtain biological data and conversion factors for some elasmobranchs. We have collected data from ICES Division/Sub-areas VI, VII VIIab VIIIc and IXa for rays and the small-spotted catshark (Scyliorhinus canicula) (Fig. 1).

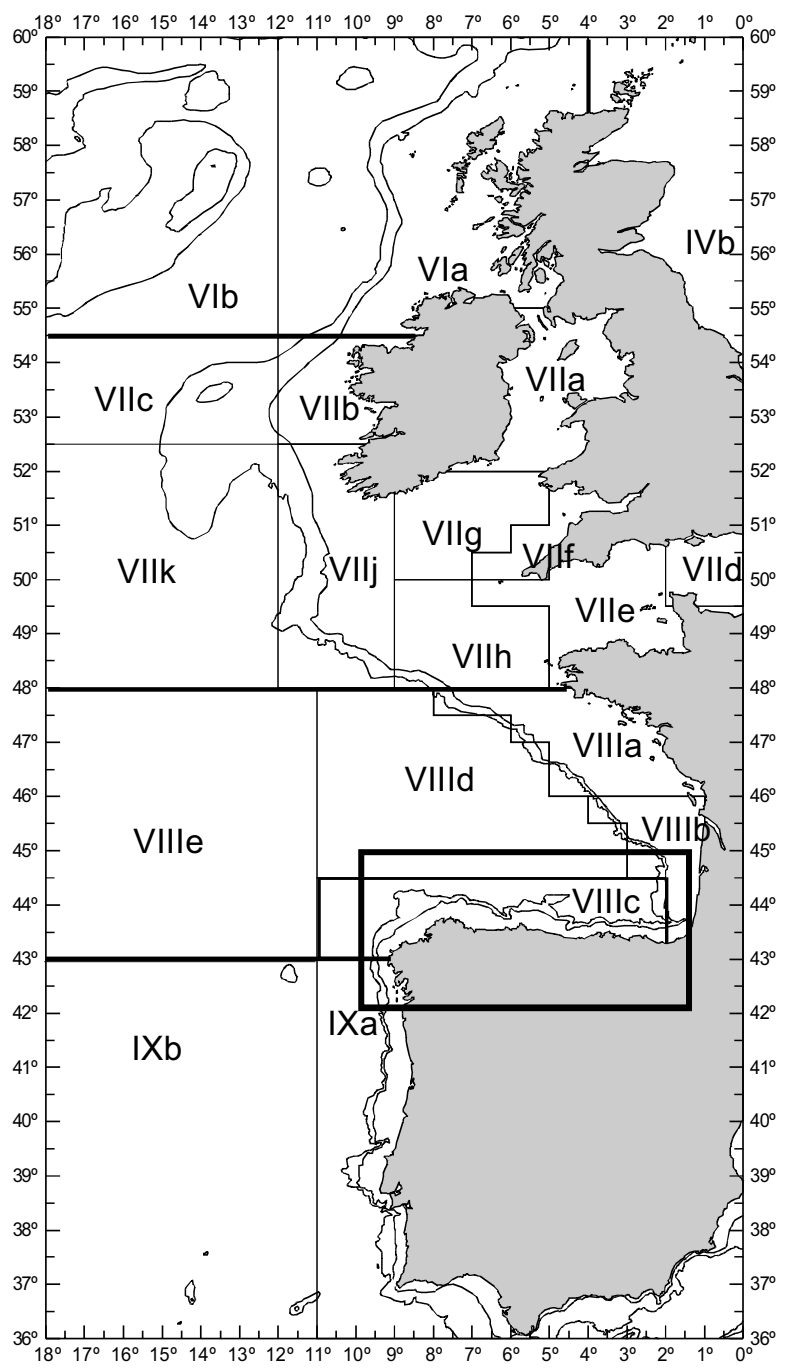

Fig. 1. Map showing the different ICES fishing Sub-areas and Divisions in the Northeast Atlantic. The box illustrates the area of study.
Four fishing ports were visited quarterly, La Coruña, Burela, Aviles and Santander (Fig. 2). The number of specimens sampled by quarter and gear is shown in Table 1. Samples of rays were obtained from a total of 43 vessels (8 employing gillnets, 8 longlines and 27 otter trawls). Small-spotted catshark samples were obtained from a total of 26 vessels ( 6 employing gillnets, 5 longlines and 15 otter trawls).

For rays, different measurements were taken according to the way fish were landed; total length (TL, cm), disc width (DL, cm) and wing length (WL, cm). Conversion factors were used to obtain the total length in all cases (Fernández et al., MS 2001). For small-spotted catshark, total length was measured $(\mathrm{TL}, \mathrm{cm})$ from the snout to the caudal tip to the nearest $\mathrm{cm}$.

Information on vessel characteristics was gathered through the official census made in 2000 and by interviews in the fishing ports. The information provided here can be considered as the best possible estimates of catch data since it is not always possible to record data from all the fishing ports at a species level or to know the specific fishing area or fishing gear.

\section{Results}

The Spanish fleet has traditionally fished in the North Atlantic (ICES Sub-areas VI, VII and in Divisions VIIIa, b, c, $\mathrm{d}$ and IXa) (Fig. 1) targeting the main commercial species; hake (Merluccius merluccius), monkfish (Lophius sp.), megrim (Lepidorhombus sp.), sole (Solea sp.), etc. The description of elasmobranch fisheries in the different ICES Sub-areas and Divisions is difficult given that the majority of elasmobranchs are not important commercial species in Spain. Most are taken as by-catch in different fishing gears, mostly discarded. For the purpose of distinguishing and characterising commercial fisheries, elasmobranchs have been divided into four groups: pelagic sharks, deepwater sharks, demersal sharks, and skates and rays.

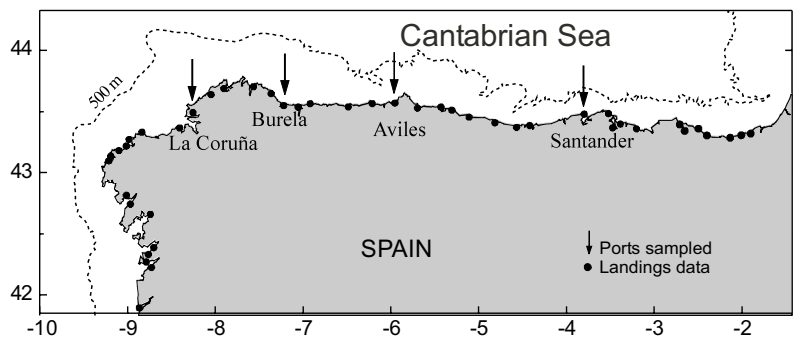

Fig. 2. Location of the main fishing ports where landings data were collected and market sampling was carried out. 
TABLE 1. Number of specimens sampled by gear in four fishing ports from ICES Division VIIIc.

\begin{tabular}{lrrrrr}
\hline \hline Year & Quarter & \multicolumn{5}{c}{ Gillnet } & Longline & Trawl & Total \\
\hline \multicolumn{5}{c}{ a) } & Scyliorhinus canicula \\
2000 & 4 & 205 & 55 & 382 & 642 \\
2001 & 1 & 62 & - & 334 & 396 \\
2001 & 2 & 16 & 148 & 411 & 575 \\
2001 & 3 & 49 & 45 & 233 & 327 \\
2001 & 4 & - & 78 & 252 & 330 \\
Total & & 332 & 326 & 1612 & 2270 \\
& & & & &
\end{tabular}

b) Rajidae species

\begin{tabular}{lrrrrr}
2000 & 4 & 50 & 79 & 621 & 750 \\
2001 & 1 & 88 & 1 & 625 & 714 \\
2001 & 2 & - & 230 & 246 & 476 \\
2001 & 3 & - & - & 52 & 52 \\
2001 & 4 & - & - & 58 & 58 \\
Total & & 138 & 310 & 1602 & 2050 \\
\hline
\end{tabular}

\section{Pelagic sharks}

The most representative species of this group is the blue shark (Prionace glauca) which supports a localised seasonal fishery, mainly between June and November, a few longline vessels operating in the south-eastern area of the Bay of Biscay with basis in the Basque port of Ondarroa. Landings of blue shark fluctuated between 470 tons in 1996 and 177 tons in 1999. In the ICES Division VIIIc, this species is mostly caught with surface longline, and only occasionally with trawl, gillnet and purse seine. The average of blue shark landings for the period 1996-2001 is about 326 tons per year (Fig. 3). The contribution of this species to the total elasmobranchs landings ranges from $14 \%$ to $27 \%$ (Fig. 4 ).

In addition to this species, porbeagle (Lamna nasus), shortfin mako (Isurus oxyrinchus), and thresher shark (Alopias vulpinus) are caught as by-catch mainly in longlines but occasionally in gillnets, purse seine and trawls. The two species are commonly reported as a single group under the name of "Marrajo", although landings of the former in some fishing ports have been reported in the last years, when it is apparently more frequent. As with other elasmobranch species, defining the fishing area may not be possible. Available data for these species, recorded as Lamnidae in Fig. 3 show fluctuations between years with an annual average of 30 tons.

\section{Deep-water sharks}

With the exception of a localised seasonal fishery targeting deep-water sharks from the fishing port of San Vicente de la Barquera, all deep-water species in the study area are taken as by-catch. The family Squalidae comprises many deep-water elasmobranchs that are commonly landed together. Many of the species caught belong to the family Squalidae: velvet belly shark (Etmopterus spinax), Portuguese shark (Centroscymnus coelolepis), leafscale gulper shark (Centrophorus squamosus), birdbeak dogfish (Deania calceus), kitefin shark (Dalatias licha) and knifetooth dogfish (Scymnodon ringens).

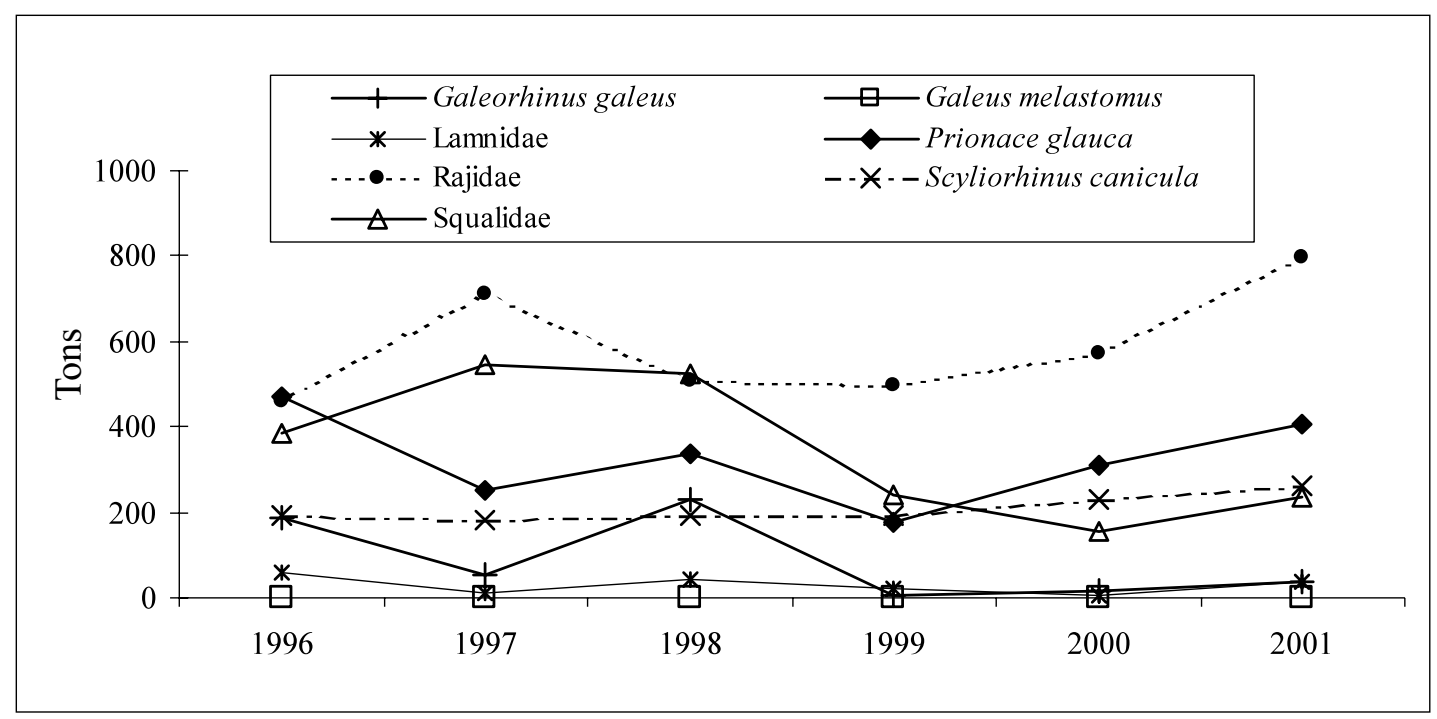

Fig. 3. Landings of the most abundant elasmobranch species in ICES Division VIIIc. 

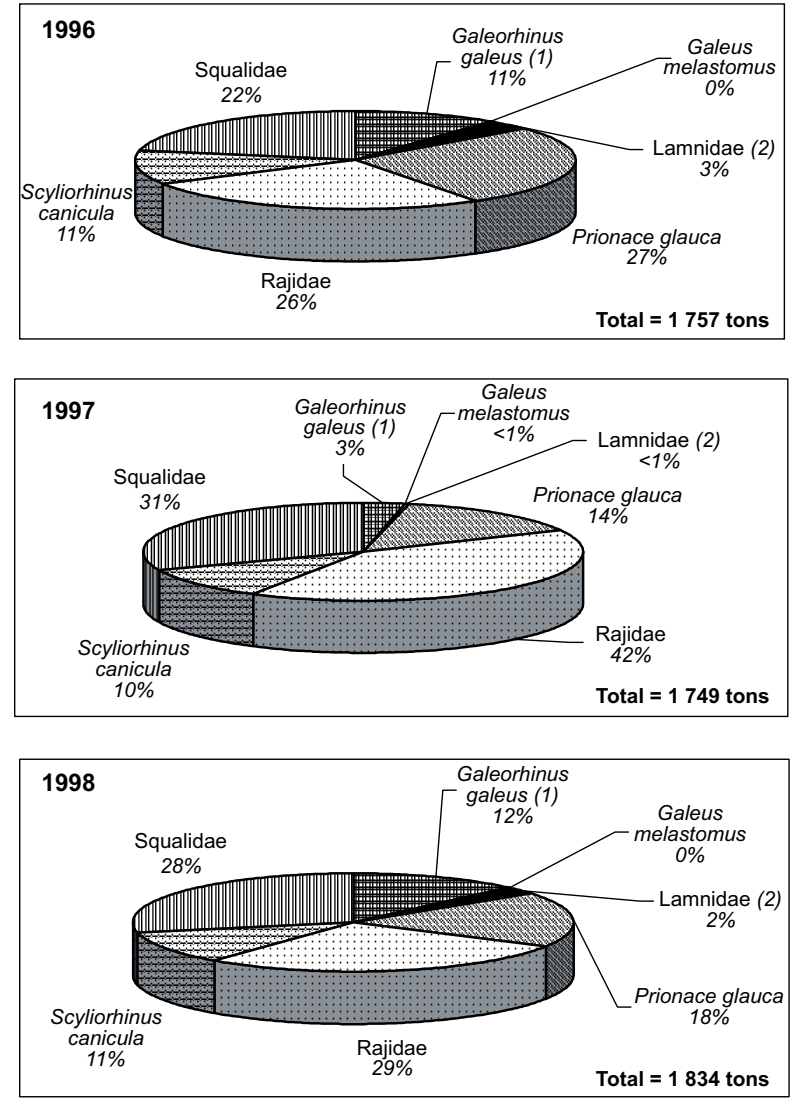
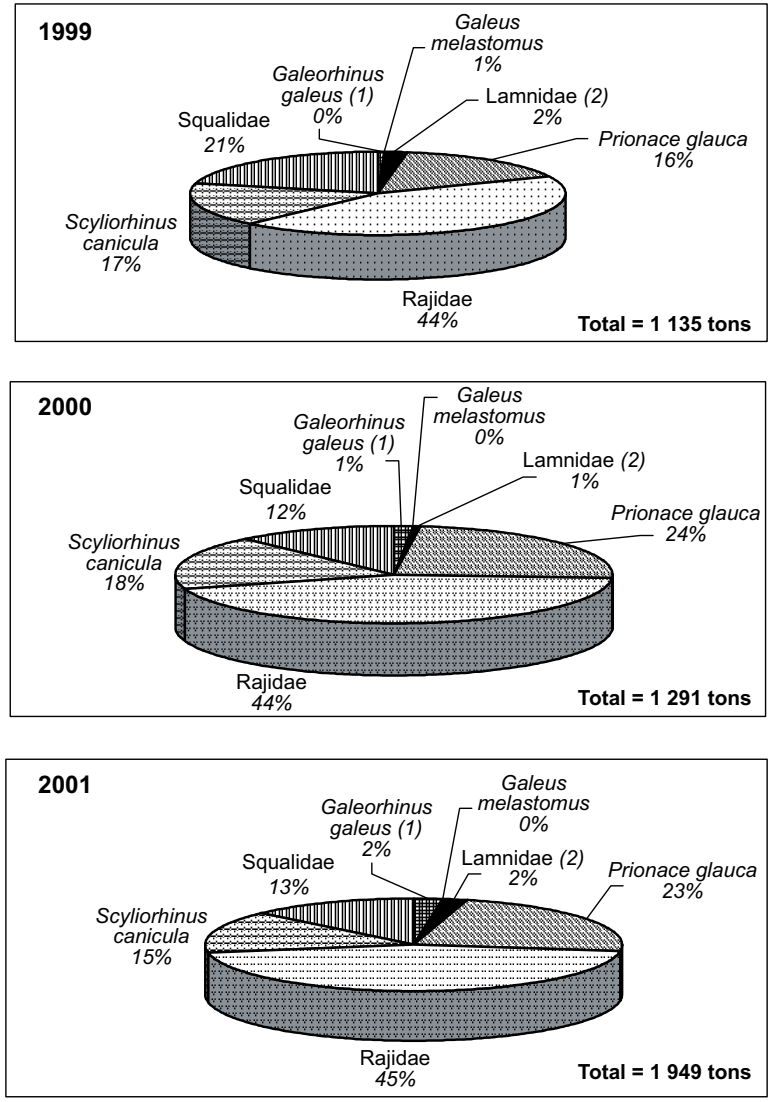

Fig. 4. Landings of the main elasmobranch species in ICES Division VIIIc for the period 1996-2001.

The other significant species caught mainly by otter trawl in ICES Divisions VIIIc and VIIIab is the black mouth catshark (Galeus melastomus), usually not mixed with other species. However, this species represents only $1 \%$ of the total elasmobranch landings (Fig. 4). Landings of this species have decreased in recent years, although it is probable that data from some fishing ports are missing and landings may be underestimated.

Landings of deep-water sharks reached 543 tons in 1997 decreasing in the following years with a slight rise in 2001 to 233 tons (Fig. 3). The contribution of squalids to the total elasmobranch landings fluctuated between $12 \%$ and $31 \%$ (Fig. 4 ).

\section{Demersal sharks}

This group comprises small-spotted catshark (Scyliorhinus stellaris), nursehoundspurdog (Squalus acanthias) and tope shark (Galeorhinus galeus). Spurdog and nursehound are both present in the Bay of Biscay, but small-spotted catshark comprises nearly all of the catch. Not all fishing ports report spurdog as a separate species.
Small-spotted catshark landings from ICES Divisions VIIIab and VIIIc are the highest, showing fluctuations among the different years with the highest values in 1998 (340 tons) and 2001 (259 tons) (Fig. 5a). These are followed by landings in Sub-area VII and Division IXa, while landings from Sub-area VI are the lowest. Landings from Division VIIIc remain close to 200 tons but have increased in the last two years. The highest landings are from bottom trawls $(75 \%)$ followed by longline $(21 \%)$ and gillnet (3\%). Landings from purse seine or traps have occasionally been recorded (Fig. 6).

Most specimens of small-spotted catshark landed were 40-66 cm TL (Fig. 9). No great differences exist in the size structure of the catches of the different fishing gears, with the mean size of specimens caught by trawl, longline and gillnet being $53.6 \mathrm{~cm}, 55.2 \mathrm{~cm}$ and $54.0 \mathrm{~cm}$, respectively. Considering that length of first maturity of females is $54.5 \mathrm{~cm}$ (Rodríguez-Cabello et al., 1998), most specimens landed are adults.

Although tope shark is taken mainly as by-catch in the longline fishery, it has been included in this group 

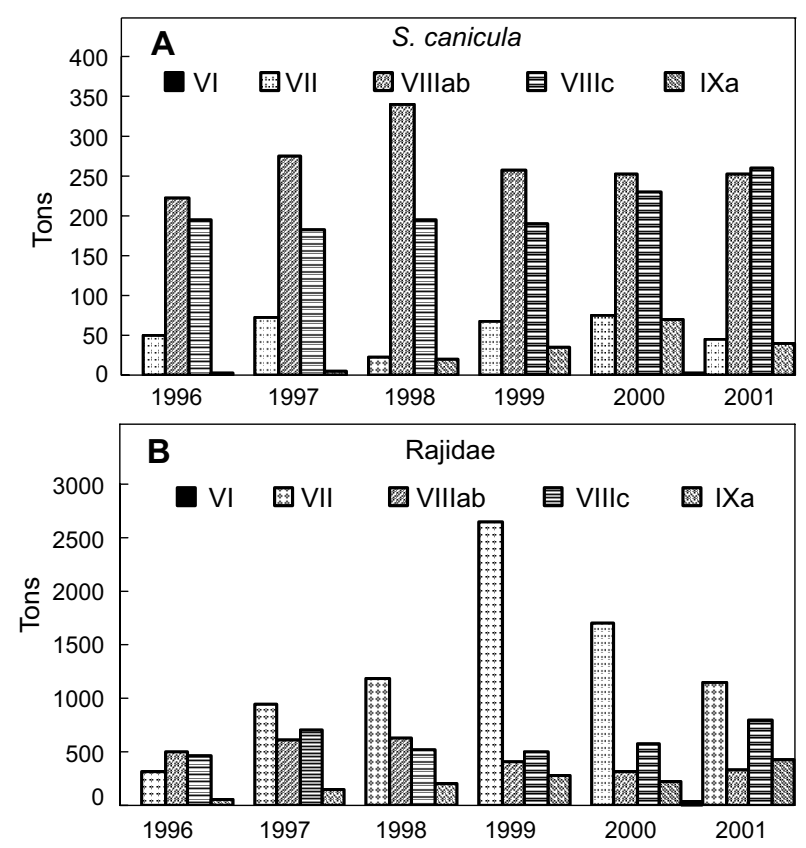

Fig. 5. Landings (kg) of (A) Scyliorhinus canicula and (B) Radidae (Raja sp.) by the Spanish fleet in ICES Subareas and Divisions.



Fig. 6. Small-spotted catfish (Scyliorhinus canicula) landings $(\mathrm{kg})$ by fishing gear in ICES Division VIIIc.

because it is more frequently found near the coast and also caught near the bottom in gillnet and trawl fisheries. It is caught primarily in the western part of the Cantabrian Sea (Galicia). About $80 \%$ of the landings are from longline vessels, the rest from trawlers and small gillnetters. Some fluctuations are apparent in total landings and are thought to be due to lack of reporting from the most important port for these landings since 1998. For this reason, it is uncertain whether landings have decreased in recent years (Fig. 3).

\section{Rays}

Ray landings (species combined) from the Spanish fleet operating in ICES Sub-area VII, peaked at 2

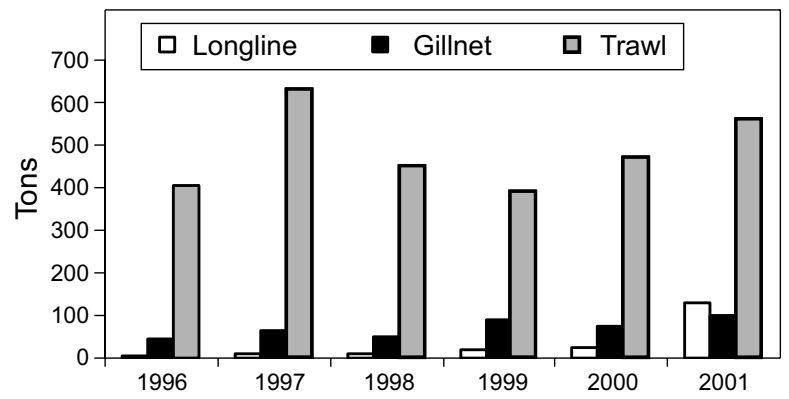

Fig. 7. Rajidae landings (kg) by fishing gear in ICES Division VIIIc.

647 tons in 1999 (Fig. 5b). Landings from Division VIIIab and VIIIc are approximately 500 tons in each area. Landings from Division VIIIab reveal a decreasing trend, while an increasing trend is evident from Division VIIIc. Landings from Division IXa and Sub-area VI are scarce. Annual landings of rays are approximately 500 tons, with an increasing trend in the last two years. The highest landings from Division VIIIc are from trawls $(81 \%)$ followed by gillnets $(11 \%)$ and longlines $(8 \%)$. Occasional landings with purse seine or traps have also been recorded (Fig. 7).

The main ray species found in the commercial Spanish landings are spotted ray (Raja montagui), thornback ray, $(R$. clavata), cuckoo ray (Leucoraja naevus), blond ray $(R$. brachyura), undulate ray ( $R$. undulate), smalleyed ray ( $R$. microocellata), long-nosed skate (Dipturus oxyrinchus) and sandy ray (R. circularis). Based on market sampling carried out in 2000-01, spotted, thornback and cuckoo ray are the most abundant rajids in the landings from Division VIIIc, while undulate and sandy ray are scarce. However, significant differences exist among fishing gears. For example, blond ray represents $30 \%$ of gillnet landings but it is not usually landed by other gears. Landings of thornback ray are consistently $>20 \%$ of the catch for all gears, most predominant in longlines (Fig. 8).

The estimated proportions of rays discarded in ICES Division VIIIc were 20\% in 1994, 25\% in 1999 and 33\% in 2000, respectively (Table 2 ). The catch composition and length distributions of the main ray species in Division VIIIc is described below.

Spotted ray: Approximately $84 \%$ of landings come from trawls, total length of fish ranging from 30 to $90 \mathrm{~cm}$. Gillnet and longline landings represent around $8 \%$ each; gillnet catches include some small specimens $<20 \mathrm{~cm}$, while longline catches comprise medium-sized specimens, mainly from 45 to $60 \mathrm{~cm}$ (Fig. 9). 
Thornback ray: The length distribution of this species in trawl landings (80\%) ranges from 32 to 95 $\mathrm{cm}$. Gillnets, which yield $\sim 6 \%$ of the landings, retains

specimens mainly 50 to $70 \mathrm{~cm}$ fish. Longline (14\%) also covers a length range as wide as trawl, but most of the individuals landed are 45 to $55 \mathrm{~cm}$ (Fig. 9).

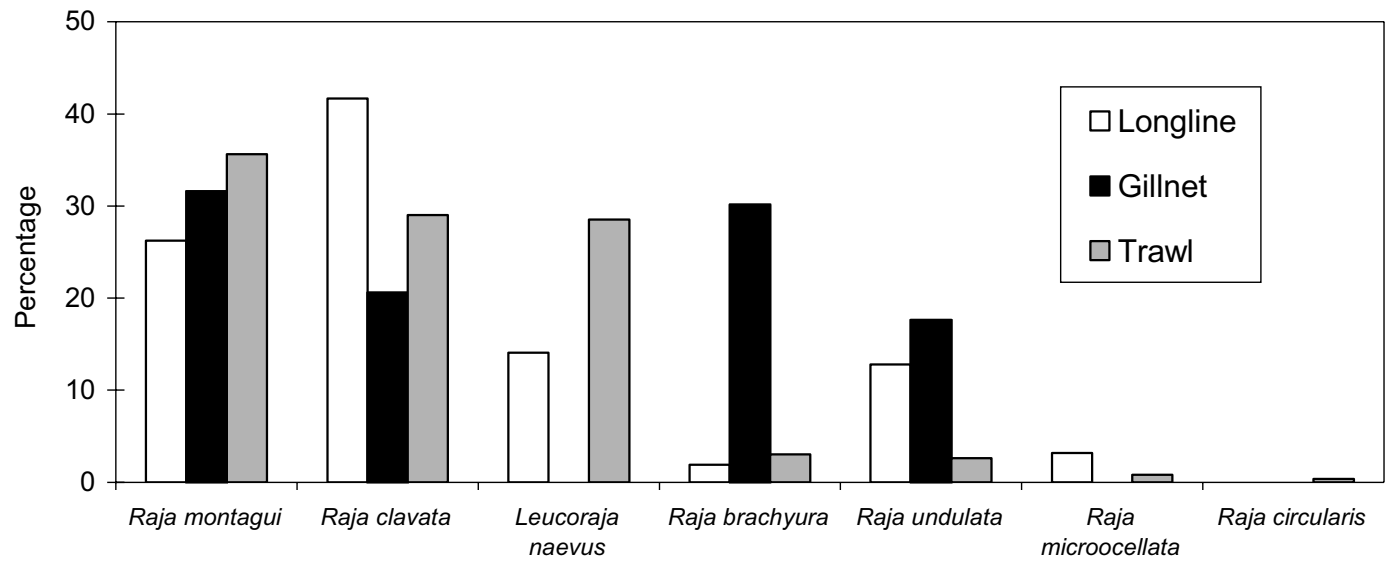

Fig. 8. Species composition of landings of Rajidae from ICES Division VIIIc, based on a market sampling program carried out in $2000-01$.

TABLE 2. Percentage of discards estimated for the Spanish otter trawl fleet in ICES Division VIIIc.

\begin{tabular}{lccc}
\hline \hline & 1994 & 1999 & 2000 \\
\hline Rajidae & 19.8 & 24.9 & 33.1 \\
Scyliorhinus canicula & 90.0 & 77.4 & 82.6 \\
\hline
\end{tabular}
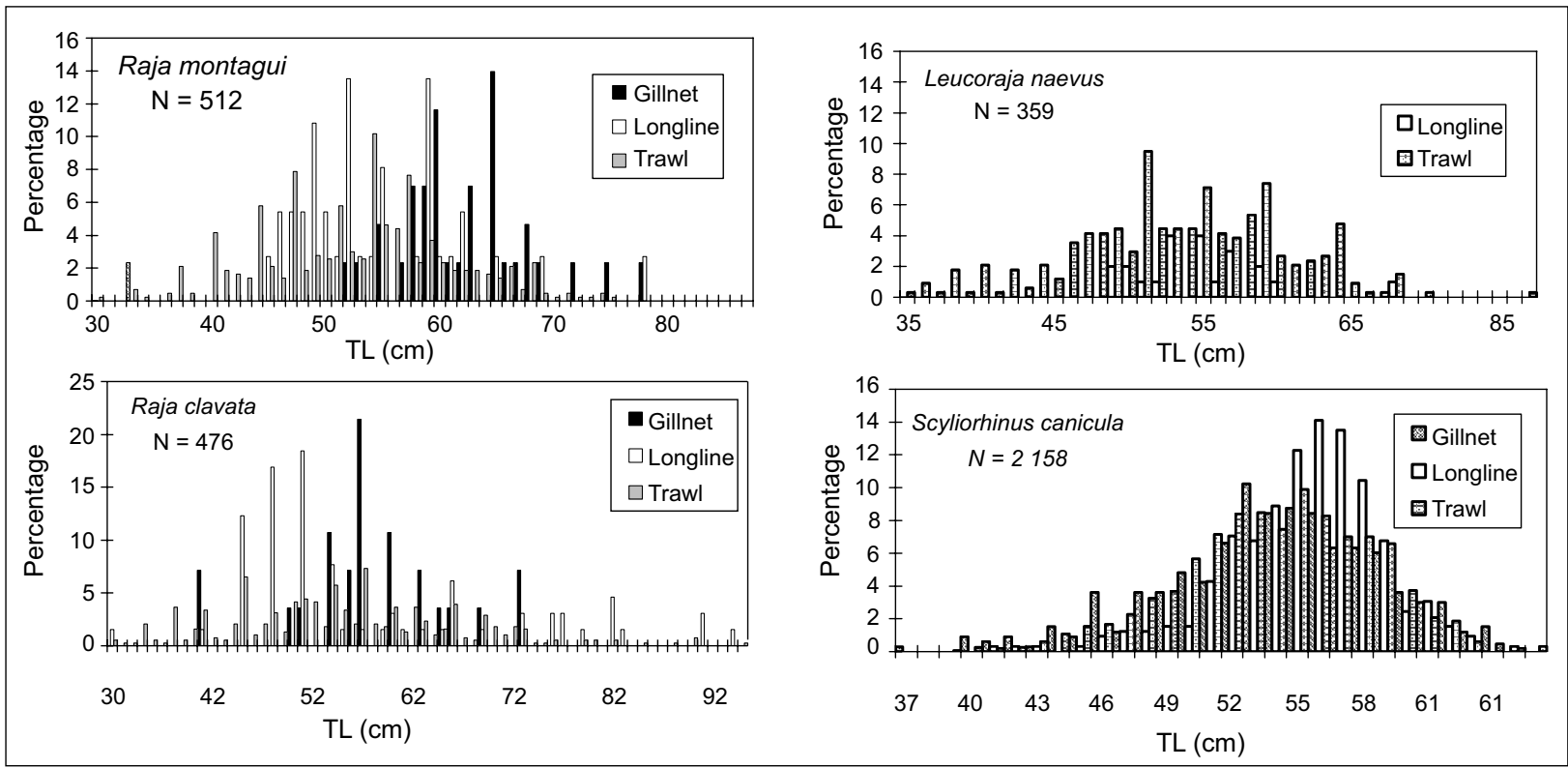

Fig. 9. Length composition (TL) of the catch of the main Rajidae species and small-spotted catshark. 
TABLE 3. Characteristics of the total fleet operating in Cantabrian Sea based on a census in 2000 (Instituto Español de Oceanografia database).

\begin{tabular}{|c|c|c|c|c|c|}
\hline & \multirow[b]{2}{*}{ Trawl } & \multirow[b]{2}{*}{ Longline } & \multicolumn{2}{|c|}{ Gillnet } & \multirow{2}{*}{$\begin{array}{c}\text { Small } \\
\text { Artisanal }\end{array}$} \\
\hline & & & Volanta & $\overline{\text { Rasco }}$ & \\
\hline No. of vessels & 167 & 207 & 85 & 78 & 7942 \\
\hline HP mean & 500 & 130 & 160 & 80 & 20 \\
\hline GRT mean & 150 & 20 & 25 & 10 & 3 \\
\hline Length mean & 27 & 14 & 16 & 11 & 6 \\
\hline Years & 21 & 20 & 17 & 21 & 29 \\
\hline
\end{tabular}

Cuckoo ray: Only specimens from longlines (6\%) and trawls (94\%) have been sampled. There were no gillnet landings recorded for this species during the study period. The length distribution of the trawl catch ranges from 35 to $77 \mathrm{~cm}$, while longline catches generally consist of medium-sized specimens from 47 to $67 \mathrm{~cm}$ (Fig. 9).

\section{Discussion}

The latest fleet census carried out in 2000 estimated that 8479 vessels were fishing in the Cantabrian Sea, 277 less than in 1998. One hundred and sixty-seven vessels operated with trawl gear, 207 with longline, 163 with gillnet and the rest were small boats working near the coast with artisanal gears, $90 \%$ in Galicia, north-western Spain. Trawlers are the largest vessels, with mean sizes of $500 \mathrm{HP}, 150 \mathrm{GRT}$ and $27 \mathrm{~m}$ length. Gillnet and longline vessels are very similar in size, around 130-160 HP, 20-25 GRT and 14-16 m length. Most of the fleet is $>20$ years old (Table 3).

For vessels taking rays in La Coruña, Burela, Aviles and Santander, the average fishing days range between one day (gillnet vessels) to six days (some longline and otter trawl vessels). The average fishing time vessels taking small-spotted catshark was one day for gillnet and longline vessels and 1.5 days for otter trawl vessels.

The demersal fishery along the north and north-west coasts of Spain is a multi-species, multi-gear fishery. Traditionally, the gears used in the Cantabrian Sea are classified in four types: trawl, longline, gillnet and purse seine. (Table 4). Other gears are grouped as "small artisanal".

Each gear type includes several varieties depending on the target species (González et al., 1986, Punzón and Gancedo, MS 1998, 2000). The term gillnet encompasses several bottom gears targeting different species (Rodríguez and Santamaría, 1923; Pereda and Villamor MS 1991). Rasco is a gillnet for anglerfish in one single piece, with mesh size of $280 \mathrm{~mm}$ usually deployed at depths between 100 and $800 \mathrm{~m}$ (Pereda et al., MS 1998). Volanta is a gillnet for hake made up of a single piece, with a $80 \mathrm{~mm}$ minimum mesh size, frequently set at 100 to $400 \mathrm{~m}$ depth. Included in "small artisanal gears" are all those deployed at depths $<150$ m near the coast: beta, a single piece gillnet with a mesh size not less than 60 $\mathrm{mm}$; trasmallo, three overlapping pieces with mesh size not less than $400 \mathrm{~mm}$ in the two outer pieces and $60 \mathrm{~mm}$ in the inner piece; miño similar to the trasmallo but made up of three pieces with mesh size not less than $500 \mathrm{~mm}$ in the two outer pieces and $90 \mathrm{~mm}$ in the inner piece. These gears are mainly modifications of the ones previously described (Punzón and Gancedo, MS 1998).

\section{Deep-water sharks}

Deepwater sharks comprise by-catch from mixed fisheries in the study area. A longline fishery targeting deep-water sharks occurred briefly between 1991 and 1995 in ICES Sub-areas VI and VII, but the fleet subsequently returned to the traditional fishery for hake (Piñeiro et al., 2001). In recent years, the landings of deep-water sharks have increased, especially in the northern ICES Sub-areas. Apart from Portugal and Azores, no country reported landings of deep-water sharks by species, but rather as "squalidae or various" (STECF, 2002). Our study has determined that the most frequent species found in the by-catch of the Spanish fleet in ICES Division VIIIc are velvet belly shark, leafscale gulper shark, Portuguese shark, birdbeak dogfish and kitefin shark. The main deep-water sharks landed are the leaf-scale gulper shark and the Portuguese dogfish due to their high commercial value. They are usually reported under the name "siki" (Heessen, 2003). A similar mix of species is reported in other ICES areas.

\section{Demersal Sharks}

Small-spotted catshark is the most important demersal shark landed from ICES Divisions VIIIa, $b$ and VIIIc and the most important elasmobranch by-catch species in the otter trawl fishery, after the rays. It is also the most 


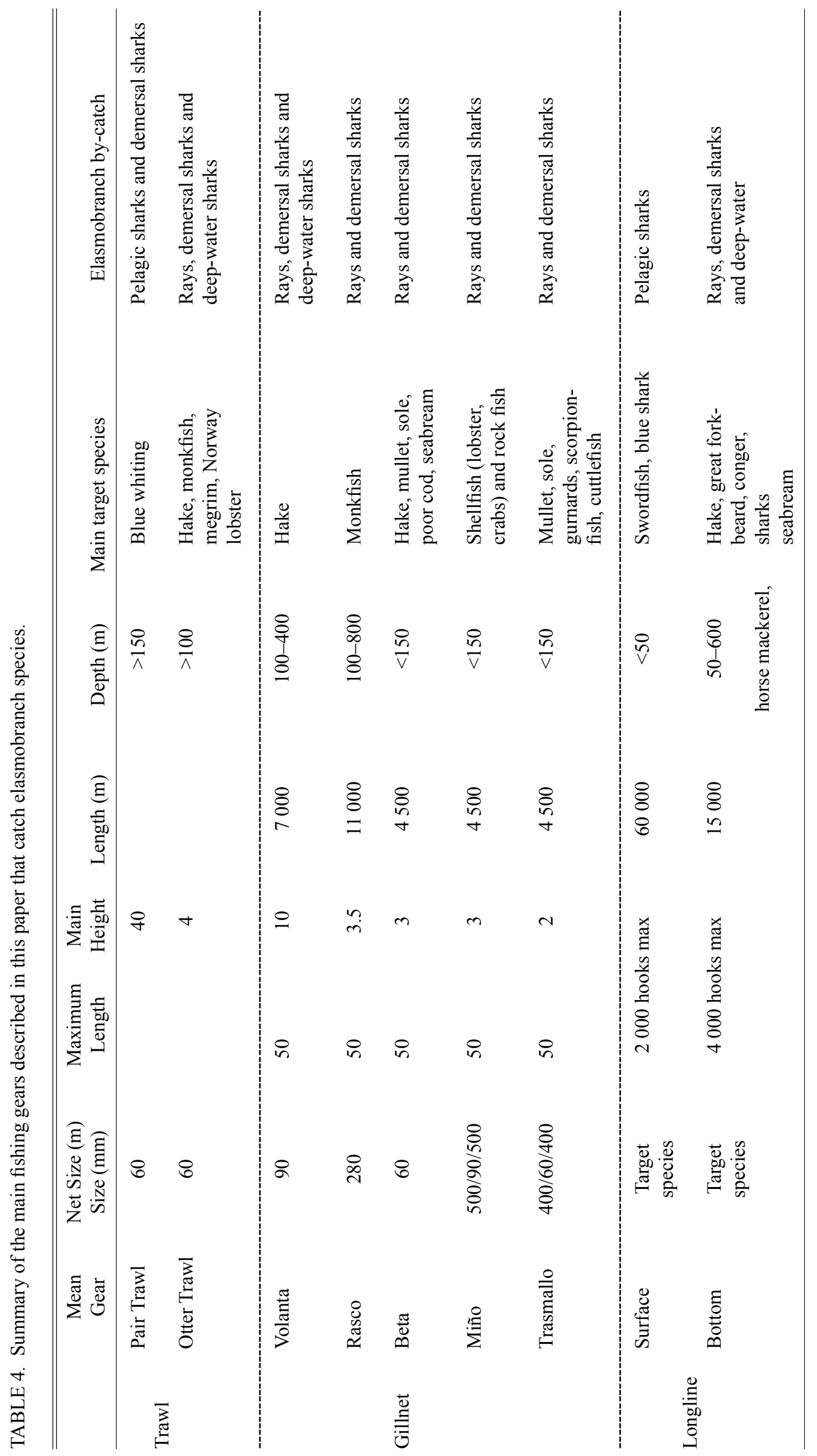


important catshark landed by the French fleet mainly from the Celtic Sea and the English Channel. In that fishery, it is taken as by-catch from trawls and longlines with similar percentages to those obtained for the Spanish fleet: $81 \%$ for trawlers and 14\% for longliners in 1987 (ICES, MS 1989). Landings of this species in ICES Division VIIIc have remained close to 200 tons per year while in France, landings have also been stable since 1980; 4000 to 6000 tons per year (Heessen, 2003). In Belgium, total landings in recent years have fluctuated around 390 tons per year and UK landings for the period 1996-2001 average 212 tons per year, similar to the results of our study. However those landings come mainly from Divisions VIId-e, VIIa and IVc to the north (Heessen, 2003).

A high proportion of small-spotted catshark is discarded. A study carried out in 1994 indicated that almost $90 \%$ of the total Spanish catch of small-spotted catshark in ICES Division VIIIc is discarded (Pérez et al., 1996). Similar percentages are observed for the Basque country otter trawl fleet in Divisions VIIIa, b and d, where the proportion of total catch by number discarded in 2000 was 82\% (Lart et al., 2002). Data on discards are not available for many European countries. However, since this species is widely distributed and abundant, it seems likely that substantial discarding of this species occurs elsewhere. Where it is not marketable such as in Scotland, most of the catch is discarded (Heessen, 2003).

Our study shows that most small-spotted catshark landed are $40 \mathrm{~cm}$ to $66 \mathrm{~cm}$. This is similar to the results of other studies carried out in this area for otter trawlers (Rodríguez-Cabello et al., MS 2001). Estimated length distributions of discarded and retained small-spotted catshark in adjacent waters (Divisions VIIIa, b and d) from the Basque trawl fishery in 2000 show similar sizes caught (Lart et al., 2002).

There is no directed commercial fishery for tope shark in European waters, but they are taken as by-catch in bottom trawl, net and line fisheries of all countries bordering the Northeast Atlantic, particularly by French vessels fishing in the English Channel, western approaches and northern Bay of Biscay (Bonfil, 1994). Bottom trawl surveys indicate this species is scarce in this area (Sánchez et al., 2002).

\section{Rays}

Rays landed from the Northeast Atlantic are taken mainly as by-catch from bottom trawl fisheries. France, Ireland and the UK have landed the largest proportion of the catch from seasonal directed fisheries (ICES, MS 1995). Although skate and ray landings appear to be stable in the Northeast Atlantic, the relative abundance of some species has changed. Available information suggests high fishing mortalities of certain species (ICES, MS 1989).

We have observed that the most abundant landings of rays species from ICES Division VIIIc were thornback, spotted, and cuckoo ray. Similar results are obtained from the series of bottom trawl surveys carried out in autumn in this area (Sánchez et al., 2002). Cuckoo ray has contributed over $30 \%$ of the total French catch in recent years, taken mainly from the southern part of the Celtic Sea (Division VIIh) and the northern part of the Bay of Biscay (STECF, 2002).

Our study indicated that the highest ray landings of the Spanish fleet come from the ICES Sub-area VII. Most of the French catches are also taken in this area, particularly the Celtic Sea and English Channel (STECF, 2002). In the North Sea landings of rays and skates underwent a major decline since 1965 and where once the thornback ray had been the most abundant ray species, the starry ray (Amblyraja radiata) now comprises $80 \%$ of the biomass of the Rajidae landed (Walker and Heessen, 1996).

In the past, the common skate (Dipturus batis) was distributed throughout the central and northern North Sea, but in the last few decades appears to have retreated north to a small part of the North Sea. It is currently caught only off the Shetland Islands (Walker, 1998) and is rare in landings in all areas (ICES, MS 2003). No landings data are reported for the Spanish fishery in ICES Division VIIIc and according to the Instituto Español de Oceanografía (IEO) bottom trawl surveys it is extremely rare there. However, data on discards of the Spanish fleet in different ICES Sub-areas show some catches of this specie in Sub-areas VI and VII (Pérez et al., 1996).

\section{Conclusions}

Through the DELASS project (Heessen, 2003), considerable progress has been made in making data available for stock assessment of elasmobranch species. Information has become available on the species composition of elasmobranch catches, particularly for rays. Additional information on length frequency distributions, biological data and conversion factors were obtained. Future research must be done to improve the fishery and biological data, essential requirements to provide future advice in management and conservation of elasmobranch species.

\section{Acknowledgements}

Many colleagues were involved in the collection data from the fishing ports, sampling and processing the information. We are very grateful to the Instituto Español 
de Oceanografía (IEO) data base team of La Coruña, especially to Roberto Morlán, and Baltasar Patiño from Vigo IEO, who provided information from Galicia main fishing ports. We would also like to extend our thanks to the Technological Fishery and Food Institute (AZTI) specially to Iñaki Arteche and Guzmán Díez who assisted with data from the Basque fishing ports.

\section{References}

BONFIL, R. 1994. Overview of world elasmobranch fisheries. FAO Fish. Tech. Pap., No. 341. FAO, Rome, 119 p.

BUENCUERPO, V., S. RÍOS, and J. MORÓN. 1998. Pelagic sharks associated with the swordfish, Xiphias gladius, fishery in the Eastern North Atlantic Ocean and Strait of Gibraltar. Fish. Bull., 96: 667-685.

CASTRO, J., J. M. DE LA SERNA, D. MACIAS, and J. MEJUTO. 2000. Estimaciones científicas preliminares de los desembarcos de especies asociadas realizadas por la flota española de palangre de superficie en 1997 y 1998. SCR Doc. 99/082. ICCAT Collect. Sci. Pap., 51(1): 1882-1894.

FERNÁNDEZ, A., C. RODRÍGUEZ-CABELLO, I. OLASO, F. SÁNCHEZ, and A. SERRANO. MS 2001. Biometric relationships to estimate length and weight of Leucoraja naevus, Raja montagui and $R$. clavata, from wing landings in Cantabrian Sea. ICES C. M. Doc., No. J:48 (poster).

GONZÁlez, S., A. LAVÍN, V. ORTIZ, P. PEREDA, F. SÁNCHEZ, and B. VILLAMOR. 1986. La pesca en Cantabria (1965-1985). Gobierno de Cantabria. Consejería de Ganadería, Agricultura y Pesca. Servicio de Actividades Pesqueras, $307 \mathrm{p}$.

HEESSEN, H. J. L. (ed.) 2003. Development of elasmobranch assessments DELASS. Final Report of DG Fish Study Contract 99/055, $603 \mathrm{p}$.

ICES. MS 1989. Report of the Study Group on Elasmobranch Fishes. ICES C.M. Doc., No. G54, 35 p.

MS 1995. Report of the Study Group on Elasmobranch Fishes. ICES C.M. Doc., No. G3, 84 p.

MS 1997. Report of the Study Group on Elasmobranch Fishes. ICES C.M. Doc., No. G2, 123 p.

MS 2003. Report of the Working Group on Elasmobranch Fishes. Vigo, 28 April-2 May 2003. ICES C.M. Doc., No. G09.

IMM. 1997. Statement of conclusions from the Intermediate Ministerial Meeting on the integration of fisheries and environmental issues 13-14 March, 1997, in Bergen.

KEBE, P., V. RESTREPO, C. PALMA, and J. CHEATLE. 2002. An overview of shark data collection by ICCAT. SCR 01/045. ICCAT Collect. Sci. Pap., 54(4): 1107-1122.

LART, W., M. ALLEN, H. ARAUJO, M. ARMSTRONG, R. BRIGGS, R. CASLAKE, G. DÍEZ, M. FINDLAY, N. GODDEN, A. HEWER, E. HIGUES-DI-CILES, A. KINGSTON, P. LUCIO, N. PÉREZ, P. PAWSON, I. QUINCOCES, R. A. REESE, M. SANTURTUN, P. J. SCHON, R. SCOTT, A. SEARLE, and R. SENIOR. 2002. Final Report on "Monitoring of discarding and retention by trawl fisheries in Western Waters and the Irish Sea in relation to stock assessment and technical measures". EC DG Fisheries (Contract Ref. No. 98/095).

MEJUTO, J., B. GARCÍA-CORTÉS, and J. M. de la SERNA. 2002. Preliminary scientific estimations of by-catches landed by the Spanish surface longline fleet in 1999 in the Atlantic Ocean and Mediterranean Sea. SCR /01/049. ICCAT Collect. Sci. Pap., 54(4): 1150-1163.

PEREDA, P., and B. VILLAMOR. MS 1991. Artisanal fisheries in the Cantabrian Sea. ICES C.M. Doc., No. G:30 Sess. P.

PEREDA, P, A. PUNZÓN, and J. LANDA. MS 1998. The "rasco": a gillnet fishery for Anglerfish (Lophius piscatorius L., 1758 and L. budegassa Spinola, 1807) in the Cantabrian Sea (ICES Division VIIIc). ICES C.M. Doc., No. O:46 Deepwater fish and fisheries.

PÉREZ, N., P. PEREDA, A. URIARTE, V. TRUJILLO, I. OLASO, and S. LENS. 1996. Descartes de la flota española en el área del ICES. Datos y Resúmenes. Inst. Esp. de Oceanogr., 2: $142 \mathrm{p}$.

PIÑEIRO, C. G, M. CASAS, and R. BAÑÓN. 2001. The deepwater fisheries exploited by Spanish fleets in the Northeast Atlantic: a review of the current status. Fish. Res., 51: 311-320.

PUNZÓN, A., and R. M. GANCEDO. MS 1998. Specific characterisation and identification of the fishing gears in use in the Cantabrian Sea (NE Atlantic, Northern Spain). ICES C.M. Doc., No. U:7: 1-20.

PUNZÓN, A., and R. M. GANCEDO. 2000. Descripción de las pesquerías artesanales de Cantabria y Asturias (Norte de España). Inf. Téc. Inst. Esp. Oceanogr., 179: 43 p.

RODRÍGUEZ-CABELLO, C., F. VELASCO, and I. OLASO. 1998. Reproductive biology of lesser spotted dogfish Scyliorhinus canicula (L., 1758) in the Cantabrian Sea. Sci. Mar., 62(3): 187-191.

RODRÍGUEZ-CABELLO, C., A. FERNANDEZ, I. OLASO, and F. SÁNCHEZ. MS 2001. Survival of lesser spotted dogfish (Scyliorhinus canicula, L.) discarded by trawlers. ICES C.M. Doc., No. N:06.

RODRÍGUEZ SANTAMARIA, B. 1923. Diccionario de artes de pesca de España y sus posesiones. Ed. Sucesores de Ribadeneyra, S.A. Madrid.

SÁNCHEZ, F. 1993. Las comunidades de peces de la plataforma del Cantábrico. Publ. Esp. Inst. Español de Oceanogr., 13: $137 \mathrm{p}$.

SÁNCHEZ, F., F. DE LA GÁNDARA, and R. GANCEDO. 1995. Atlas de los peces demersales de Galicia y Cantábrico. Otoño 1991-1993. Publ. Esp. Inst. Español de Oceanogr., 20: 100 p.

SÁNCHEZ, F., and I. OLASO. 1999. Fisheries impacts in the Cantabrian Sea using a mass-balance model. Working document in Report of the Ecosystem Effects of Fishing Activities, ICES ACFM/ACME, 199: $19 \mathrm{p}$.

SÁNCHEZ, F., M. BLANCO, and R. GANCEDO. 2002. Atlas de los peces demersales y de los invertebrados de interés comercial de Galicia y Cantábrico. Otoño 1997-1999. CYAN (ed). Publ. Esp. Inst. Español de Oceanogr., $141 \mathrm{p}$.

STECF. 2002. Report of the Subgroup on Resource Status (SGRST) of the Scientific, Technical and Economic Com- 
mittee for Fisheries (STECF): Elasmobranch Fisheries. Brussels, 23-26 September 2002. Commission Staff Working Paper SEC (2002) 1160.

WALKER, P. A., and H. J. L. HEESEN. 1996. Long-term changes in ray populations in North Sea. ICES J. Mar.
Sci., 53: 1085-1096.

WALKER, P. A. 1998. Sensitive skates or resilient rays? Spatial and temporal shifts in ray species composition in the central and north-western North sea between 1930 and the present day. ICES J. Mar. Sci., 55: 392-402. 